\title{
SEBARAN SPASIAL VOLUME BACKSCATTERING STRENGTH IKAN PELAGIS DI DANAU RANAU, SUMATERA SELATAN
}

\author{
SPATIAL DISTRIBUTION OF PELAGIC FISH VOLUME BACKSCATTERING \\ STRENGTH IN RANAU LAKE, SOUTH OF SUMATERA
}

\author{
Aisyah $^{1}$, Totok Hestirianoto ${ }^{2}$, Sri Pujiyati ${ }^{2}$ \\ ${ }^{1}$ Program Studi Teknologi Kelautan, Sekolah Pascasarjana \\ ${ }^{2}$ Departemen Ilmu dan Teknologi Kelautan \\ Fakulltas Perikanan dan Ilmu Kelautan, Institut Pertanian Bogor \\ Korespondensi : icha_saraimanette@yahoo.com
}

\begin{abstract}
Ranau Lake classified as large lake that potentially used for drinking water supply, fishing, irrigation, transportation, and for recreation. Backscaterring strenght in hydroacoustic is an important reference parameter in estimating or quantifiying fish resources (density and distribution). The aim of this study was to quantify the result of acoustic method that used in Ranau Lake. Quantitatives data that obtained from survey might used as the base of next analysis in fisheries resources management. Research was conducted in Ranau Lake that covered South of Ogan Komering Ulu (OKU) and West of Lampung, in November 2012 and February 2013. Acoustic instrumentation used in this study was a scientific echosounder split beam EY60 frequency $120 \mathrm{kHz}$. Catch data landed in South of OKU fish landing used to verified acoustic data obtained from survey. The catch was dominated by pelagic fish. Based on Sv value, fish did not distribute evenly. Fish group distributed in littoral zone of lake spatially. Small group found in west part of lake, while the largest group concentrated in south east and east part of lake. Vertical distribution showed that all of size class (small to large) found in 0 to $75 \mathrm{~m}$ depth, while the largest size found in 75 to $125 \mathrm{~m}$ depth. Temperature and dissolved oxygen showed that the water layer stratified. Coefficient correlation showed the strong relationship between Sv and temperature (09.4), while Sv and DO showed the weak relationship (0.56).
\end{abstract}

Keywords: backscattering strength, hydroacoustic, pelagic fish, Ranau Lake

\begin{abstract}
ABSTRAK
Danau Ranau tergolong danau besar sehingga dapat dikatakan memiliki potensi yang besar untuk dimanfaatkan sebagai penyedia air minum, perikanan, irigasi, transportasi dan rekreasi. Backscaterring strenght sebagai bagian dari karakteristik hidroakustik, merupakan parameter acuan dalam mengkaji atau mengkuantifikasi sumberdaya ikan pelagis (densitas, dan sebarannya). Penelitian bertujuan mengkuantifikasi hasil dari penggunaan metode akustik yang diterapkan di Danau Ranau. Data kuantitatif yang diperoleh diharapkan menjadi dasar analisis selanjutnya dalam hal pengelolaan sumberdaya perikanan di Danau Ranau, Sumatera Selatan. Penelitian dilaksanakan di Danau Ranau yang meliputi wilayah OKU Selatan dan Lampung Barat, pada Bulan November 2012 dan Februari 2013. Penelitian menggunakan perangkat akustik split beam echosounder simrad EY60 frekuensi $120 \mathrm{kHz}$. Data hasil tangkapan yang didaratkan di Pangkalan Pendaratan ikan di wilayah OKU Selatan yang didominasi oleh ikan pelagis digunakan untuk memverifikasi data akustik. Sebaran ikan berdasarkan nilai volume backscattering strength menunjukkan penyebaran yang tidak merata. secara spasial, kelompok ikan menyebar di sisi litoral danau, hampir tidak ditemukan di sisi barat laut. Kelompok ukuran kecil ditemukan di barat daya dan selatan danau, sementara kelompok ukuran besar terkonsentrasi di tenggara dan timur. Sebaran secara vertikal menunjukkan bahwa ukuran dari semua kelompok target (kecil hingga besar) ditemukan di kedalaman 0-75 $\mathrm{m}$, sementara di kedalaman 75-125 m ditemukan ukuran yang relatif lebih besar. Suhu dan DO menunjukkan bahwa terjadi stratifikasi minor di perairan ini. Koefisien korelasi menunjukkan keeratan hubungan antara backsterring strenght dengan suhu (0.94), namun tidak demikian dengan backsterring strenght dan DO (0.56).
\end{abstract}

Kata kunci: backscattering strength, Danau Ranau, hidroakustik, ikan pelagis 


\section{PENDAHULUAN}

Danau Ranau terletak di dua wilayah administratif, yaitu wilayah Kabupaten Ogan Komering Ulu (OKU) Selatan seluas 8.42 ha dan wilayah administratif Kabupaten Lampung Barat, Provinsi Lampung dengan luas wilayah 4.17 ha (Samuel et al. 2010). Danau ini tergolong tipe danau vulkanik dengan luas permukaan air lebih kurang 12.59 ha $\left(125.90 \mathrm{~km}^{2}\right)$ dan kedalaman maksimum lebih kurang $229 \mathrm{~m}$ dan kedalaman rata-rata sebesar 78.00 m. Danau Ranau tergolong danau besar jika dilihat dari volumenya, hal tersebut merupakan potensi besar untuk dimanfaatkan seiring dengan tingginya kebutuhan akan sumberdaya karena perkembangan jumlah penduduk.

Ikan pelagis merupakan jenis yang mendiami lapisan epilimnion di suatu perairan. Pengelolaan di danau antara lain melalui penebaran, pada umumnya memanfaatkan jenis ini terkait dengan fluktuatifnya kedalaman danau. Dari segi jenis, sumberdaya ini lebih sedikit dibandingkan dengan jenis demersal namun dapat membentuk biomassa yang sangat besar sehingga merupakan salah satu sumberdaya perikanan yang paling melimpah di perairan umum (Welcomme 2001). Ikan pelagis di danau terutama di Danau Ranau merupakan jenis dominan yang tertangkap oleh nelayan setempat (Gambar 2).

Volume backscattering strength (Sv) merupakan kuat hamburan dari sekelompok single target. Sv digunakan untuk mengestimasi kepadatan suatu kelompok ikan yang selanjutnya dianalisis lebih lanjut dalam menentukan kelimpahan sumberdaya ikan. Sv menunjukkan nilai hamburan dari suatu kelompok ikan yang terdeteksi, semakin besar nilai Sv, maka pengelompokan target semakin besar. Semakin kecil nilai Sv yang diperoleh maka pengelompokan target yang terdeteksi akan semakin sedikit. Bisa dikatakan bahwa $\mathrm{Sv}$ merupakan dugaan ukuran kelompok ikan. Hidroakustik merupakan salah satu metode yang secara langsung dapat digunakan dalam pengkajian stok (Widodo 2002). Tujuan dari penelitian ini adalah untuk menganalisis sebaran kelompok (volume backscattering strength, Sv) target ikan pelagis di Danau Ranau. Informasi mengenai sebaran suatu stok merupakan hal penting sebagai bagian dari pengelolaan perikanan di danau.

\section{METODE PENELITIAN}

Penelitian dilaksanakan di Danau Ranau pada Bulan November 2012 dan Februari 2013. Survei akustik meliputi keseluruhan danau yang meliputi wilayah OKU Selatan dan Lampung Barat (Gambar 1). Akuisisi data akustik dilakukan terus-menerus selama periode pelayaran dengan kecepatan kapal 5-10 knot. Jalur akuisisi meliputi luasan danau sehingga memungkinkan untuk dianalisis secara spasial dengan bentuk zig-zag (Simmonds \& MacLennan 2005) dari titik awal di wilayah OKU Selatan. Pengolahan data dilakukan di Laboratorium Akustik Kelautan, Bagian Akustik dan Instrumentasi Kelautan, Departemen ITK, IPB.

Bahan yang digunakan dalam penelitian ini meliputi Peta Dasar Indonesia skala 1:25.000, data hasil tangkapan nelayan gillnet yang didaratkan di tempat pendaratan ikan di wilayah OKU Selatan, Sumatra Selatan.

Peralatan yang digunakan meliputi perangkat hidroakustik split beam echosounder simrad EY60. Papan ukur panjang ikan dan timbangan digital. Pengaturan (setting) perangkat akustik selama perekaman data disajikan pada Tabel 1.

\section{Pengolahan dan analisis data}

Pengolahan data akustik menggunakan software ECHOVIEW ver. 4.8. Analisis sebaran kelompok target dilakukan berdasarkan hasil ekstraksi berupa nilai volume backscattering ( $\mathrm{Sv}$ mean, $\mathrm{m}^{2} / \mathrm{m}^{3}$ ). Split beam echosounder menerima Sv dalam bentuk logaritma (Johannesson \& Mitson 1983; Higginbottom et al. 2009) mulai dari kedalaman 5-125m dengan strata tiap 25m. Elementary Sampling Distance Unit (ESDU) yang digunakan adalah per 100 ping, sehingga seluruh data akustik yang diperoleh berupa data echogram yang terdiri dari 58 set data, terbagi menjadi 60.300 ESDU. Data yang diolah dibatasi pada thres hold minimum -90 dB dan maksimum -20 dB. Pengolahan data dilakukan $5 \mathrm{~m}$ dari permukaan perairan untuk mengeliminasi noise yang berasal dari nearfield transduser dan noise permukaan (Simmonds \& MacLennan 2005). Batas dasar perairan ditambahkan $9 \mathrm{~cm}$ di atas garis dasar perairan yang terdeteksi, untuk menghindari masuknya echo dari dasar perairan dalam mengestimasi kelimpahan. Perhitungan 
yang bersatuan $\mathrm{dB}$ dikonversi ke dalam domain linier dan sebaliknya (Echoview 2009). Sv rerata dihitung dengan persamaan rata-rata hitung, formula standar deviasi digunakan untuk menyatakan suatu ukuran yang menggambarkan tingkat penyebaran data dari nilai rata-rata (Sumanto 2014). Hubungan Sv dengan suhu dan hubungan $\mathrm{Sv}$ dengan oksigen terlarut (dissolved oxygen, DO) dinyatakan dengan persamaan regresi linier kuadratik (Yamin et al. 2011).

Proses mengintegrasi pada setiap ESDU menggunakan level threshold maksimum dan minimum tertentu. Kemudian dilakukan integrasi berikutnya pada ESDU yang sama menggunakan fixed threshold. Metode integrasi yang digunakan adalah metode integrasi kumulatif atau menjumlahkan secara keseluruhan semua sinyal yang ada di dalam selang threshold. Teknik penjumlahan menggunakan batas maksimum-minimum thres hold (Johannesson \& Mitson 1983). Penyajian peta dan klasifikasi interval kelas Sv dengan metode Natural Breaks menggunakan Arc GIS 10.1, grafik dan tabulasi menggunakan Microsoft Excel 2007. Regresi menggunakan software Minitab 17.1.

$10 \log (\mathrm{Sv})=10 \log (\mathrm{Pr})+10 \log \left(\mathrm{r}^{2} 10^{2 \mathrm{ar}}\right)-10$ $\log \left(\mathrm{Pt} \mathrm{Go} \mathrm{ro}{ }^{2} \lambda^{2}\right.$ co $\left.\psi / 32 \Pi^{2}\right)$

$$
\begin{gathered}
\mathrm{R}=\frac{a^{2} f}{c} \\
\operatorname{sv}(d b)=10^{(\mathrm{Sv} / 10)}
\end{gathered}
$$

$$
\mathrm{Sv}=10 \log \mathrm{sv}
$$

Sv rerata $=\frac{S v 1+S v 2+\ldots+S v n}{n}$

$$
\begin{gathered}
\mathrm{s}=\frac{\sqrt{\sum(\text { Svi }- \text { Svrerata })^{2}}}{n-1} \\
\mathrm{Y}=b o+b 1 X 1+b 2 X 1^{2}+\varepsilon
\end{gathered}
$$

Di mana :

Sv : volume backscattering strength dalam decibel

Pr : power dari echo yang diterima pada terminal transducer

$r$ : jarak antara transducer dengan target

$a$ : konstanta atenuasi air

$P t$ : power yang dipancarkan ke dalam perairan

Go: peak gain

ro: backscaterring strength 1 meter dari target

$\lambda$ : panjang gelombang

$c$ : kecepatan suara di air

$\tau$ : durasi pulsa

$\psi$ : solid beam angle dua arah

$R$ : nearfield

$a:$ diameter transducer

$f$ : frekuensi

$n$ : jumlah sampel

$i$ : gambaran jenis spesies ke-i

sv : volume backscattering strength dalam bentuk linier

$s$ : standar deviasi atau simpangan baku

Svi : Sv ke-i

$Y$ : variabel response, dalam hal ini $\mathrm{Sv}$

$X$ : variabel predictor dalam hal ini suhu dan DO

bo : intercept

$b 1 \& b 2$ : koefisien regresi

$r$ : koefisien korelasi, $-1 \leq \mathrm{r} \leq+1$, korelasi erat jika : $r \geq 0.7$ dan $r \leq-0.6$, dan korelasi tidak erat jika : $-0.6<\mathrm{r}<0.7$

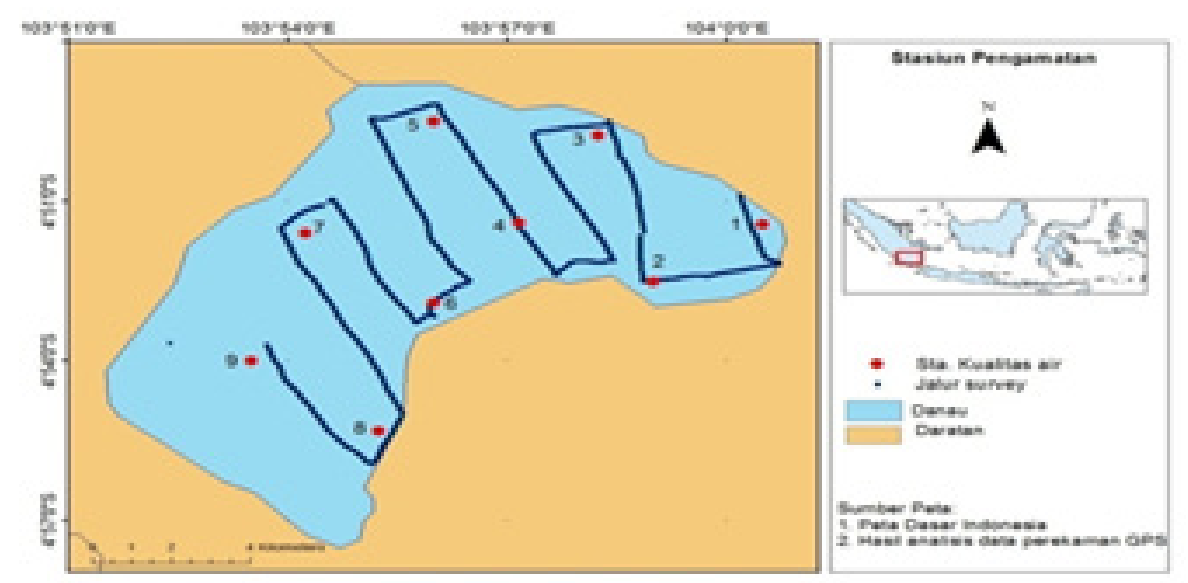

Gambar 1. Peta lokasi penelitian Danau Ranau, Sumatera Selatan 
Tabel 1. Pengaturan parameter akustik selama pengambilan data

\begin{tabular}{lc}
\hline \multicolumn{1}{c}{ Pengaturan Parameter } & Nilai \\
\hline Lingkungan & 26 \\
1. Suhu $\left({ }^{\circ} \mathrm{C}\right)$ & \\
Perangkat & 0.128 \\
1. Durasi pulsa (ms) & 50 \\
2. Keluaran daya (watt) & 0.5 \\
3. Kedalaman transduser $(\mathrm{m})$ & 120 \\
4. Frekuensi $(\mathrm{kHz})$ & 7 \\
5. Beam width $(\mathrm{deg})$ & -21 \\
6. Beam angle $(\mathrm{deg})$ & -190 \\
7. Receiving sensitivity $(\mathrm{dB}$ re $1 \mathrm{~V}$ per $\mathrm{HPa})$ & \\
echogram & $-90 \mathrm{sd} .-20$ \\
1. Sv threshold $(\mathrm{dB})$ & $20 \mathrm{log} \mathrm{R}$ \\
2. TVG & 7.32 \\
3. Panjang lintasan $(\mathrm{nm})$ & \\
\hline
\end{tabular}

\section{HASIL DAN PEMBAHASAN}

\section{Sebaran volume backscattering strength (Sv)}

Secara vertikal, ukuran kelompok ikan terbesar ditemukan di kedalaman 100-125 m dan terkecil terkonsentrasi pada kedalaman 0-75 m. Kepadatan kelompok target ditemukan maksimum pada kedalaman $75-$ $100 \mathrm{~m}$ dan terendah pada 0-25 m (Tabel 2). Jurevics et al. (2012) melalui studinya di Danau Svente menunjukkan bahwa sebaran ikan di kedalaman 0-25 m rendah seiring dengan rendahnya konsentrasi oksigen terlarut. Pada umumnya puncak konsentrasi biomassa ikan terjadi di bagian danau yang lebih dangkal, lalu menurun seiring bertambahnya kedalaman (Mason et al. 2005). Kecenderungan menurunnya jumlah target di kedalaman 100-125 m diduga merupakan gambaran awal penurunan jumlah target di kedalaman selanjutnya jika analisis terhadap data dilakukan pada area yang lebih dalam. Dari segi ukuran Sv, terlihat kecenderungan peningkatan nilai $\mathrm{Sv}$ seiring dengan bertambahnya kedalaman.

Gambar 2 terlihat bahwa secara spasial, Sv terlihat tidak menyebar rata pada seluruh danau. Pada kedalaman 0-25 $\mathrm{m}$ dijumpai ukuran $\mathrm{Sv}$ yang bervariasi (-90 sd $-36 \mathrm{~dB})$ dengan ukuran dominan -80 dB. Hampir semua ukuran ditemukan di sepanjang jalur survei, namun $\mathrm{Sv}$ berukuran relatif besar berjumlah lebih banyak di sisi tepi danau terutama di sisi timur. Sementara ukuran kecil tersebar di bagian tengah danau sebelah barat.

Sv berukuran kecil (-90 sd -80 dB) pada kedalaman 25-50 m tersebar di sisi barat danau sementara ukuran kelompok besar $(-50 \mathrm{~dB})$ tersebar di sepanjang jalur survei di tepi danau sebelah timur dan utara (Gambar 3b). Pada kedalaman ini ukuran Sv masih bervariasi dari -90 hingga $-34 \mathrm{~dB}$ dan didominasi oleh ukuran $-70 \mathrm{~dB}$. Pada kedalaman 50-75 $\mathrm{m}$ terjadi penurunan jumlah target yang terdeteksi. Ukuran $\mathrm{Sv}$ semakin menurun jika dibandingkan pada kedalaman sebelumnya (Gambar 3c) namun Sv maksimum berada pada kisaran ukuran yang relatif lebih besar yaitu $-60 \mathrm{~dB}$, dari kisaran ukuran $\mathrm{Sv}-90(\mathrm{n}=1)$ hingga $-36 \mathrm{~dB}$. Jumlah Sv di jalur 5-7 tidak sebanyak pada kedalaman sebelumnya. Beberapa studi mengenai sebaran ikan menunjukan kondisi yang sama dimana ukuran target yang relatif besar pada umumnya ditemukan melimpah seiring bertambahnya kedalaman (Jurevics et al. 2012). Secara horisontal, Sv ukuran relatif besar terkonsentrasi di tepi timur dan utara danau.

Peningkatan jumlah target terjadi pada kedalaman 75-100 $\mathrm{m}$, hal ini ditandai dengan padatnya sebaran Sv (Gambar 4d). Ukuran Sv berkisar antara $-76 \mathrm{sd}-35 \mathrm{~dB}$. Kisaran ukuran $-70 \mathrm{~dB}$ mendominasi dan menyebar rata di seluruh tepi danau baik di 
bagian barat, timur dan utara. Sementara ukuran yang relatif besar terkonsentrasi di sisi timur danau. Tingginya kepadatan $\mathrm{Sv}$ pada lapisan ini diduga disebabkan oleh adanya lapisan termoklin yang terdeteksi di sekitar kedalaman 60-80 m, sehingga beberapa target diduga terjebak di lapisan tersebut.

Kisaran ukuran Sv pada kedalaman 100-125 $\mathrm{m}$ hampir sama dengan yang dijumpai pada kedalaman sebelumnya (75$100 \mathrm{~m}$ ). Terlihat perbedaan nyata sebaran $\mathrm{Sv}$ besar dan kecil. Sv besar konsisten dijumpai di tepi danau sementara Sv ukuran kecil dijumpai di bagian tengah danau (Gambar 4e). Pada kedalaman ini ditemukan Sv besar $\left(\begin{array}{ll}-40 & d B\end{array}\right)$ yang diduga merupakan target dari famili tertentu yang memiliki toleransi lebar terhadap kondisi oksigen di lapisan hipolimnion.

Kecendrungan terkonsentrasinya $\mathrm{Sv}$ yang relatif besar di tepi atau bagian litoral danau diduga terkait dengan pola pemijahan dan keberadaan makanan. Dinamika nutrien di litoral danau cukup tinggi karena adanya pasokan dari luar (allochthonous) dari dalam perairan sendiri (autochthonous) (Peters \& Lodge 2009, Strayer 2009). Selain nutrien, alasan pemijahan menjadi sifat beberapa ikan yang membutuhkan vegetasi atau substrat tertentu. Jenis harongan (Hampala macrolepidota) dan palau (Osteochilus hasselti) dikenal berasosiasi dengan tanaman air, yang pada umumnya banyak ditemukan di bagian tepi (fishbase 2012).

Profil suhu menunjukkan bahwa lapisan epilimnion (mixed layer) berada pada kisaran kedalaman 0-60 m, termoklin (metalimnion) dijumpai pada kisaran kedalaman 60-80 $\mathrm{m}$ dan lapisan hipolimnion pada kedalaman $80 \mathrm{~m}$ hingga kedalaman maksimum yang terdeteksi oleh alat (Gambar 5a). Lapisan-lapisan tersebut terbentuk berdasarkan stratifikasi suhu dan oksigen (Gambar 5b), di mana kecenderungan kedua parameter abiotik tersebut menurun seiring bertambahnya kedalaman. Lapisan termoklin merupakan lapisan di mana perubahan suhu secara vertikal relatif besar, dimana pada Sulastri et al. (1999) dinyatakan tentang tidak jelasnya keberadaan lapisan ini di Danau Ranau. Pada penelitian ini lapisan epilimnion cenderung lebih tebal dibandingkan termoklin (metalimnion). Sementara lapisan hipolimnion merupakan yang terbesar diantaranya sebagaimana ciri danau dalam.

Tabel 2. Perbandingan Sv per strata kedalaman

\begin{tabular}{cccccc}
\hline \multirow{2}{*}{$\begin{array}{c}\text { Strata } \\
\text { Kedalaman }(\mathrm{m})\end{array}$} & \multicolumn{5}{c}{ Sv $(\mathrm{dB})$} \\
\cline { 2 - 6 } & Terendah & Tertinggi & Rata-rata & Stdev. (dB) & $\mathrm{n}$ \\
\hline $0-25$ & -90.90 & -36.10 & -81.00 & -9.63 & 2446 \\
$25-50$ & -90.90 & -34.90 & -77.60 & -9.07 & 4570 \\
$50-75$ & -90.60 & -36.50 & -70.80 & -8.47 & 3439 \\
$75-100$ & -76.70 & -35.50 & -70.30 & -7.39 & 8049 \\
$100-125$ & -76.40 & -31.50 & -67.50 & -7.91 & 7483 \\
\hline
\end{tabular}
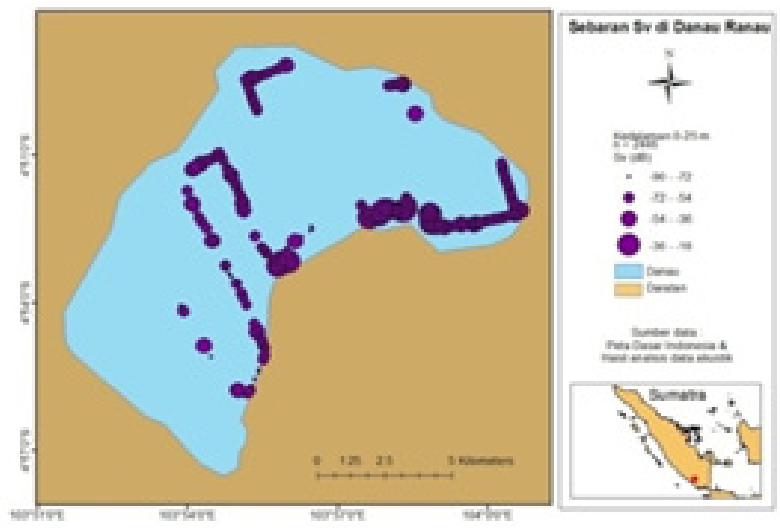

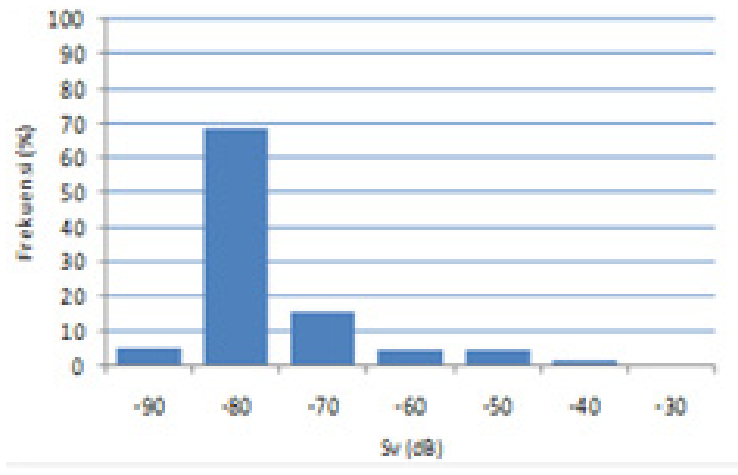

(a)

Gambar 2. Sebaran Sv (dB) pada kedalaman 0-25 m (kiri) dan sebaran ukurannya (kanan) 

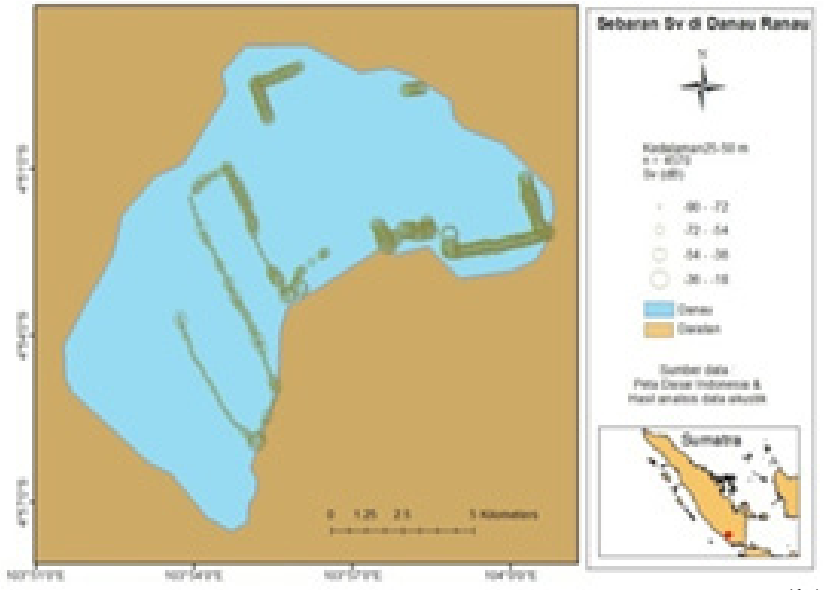

(b)
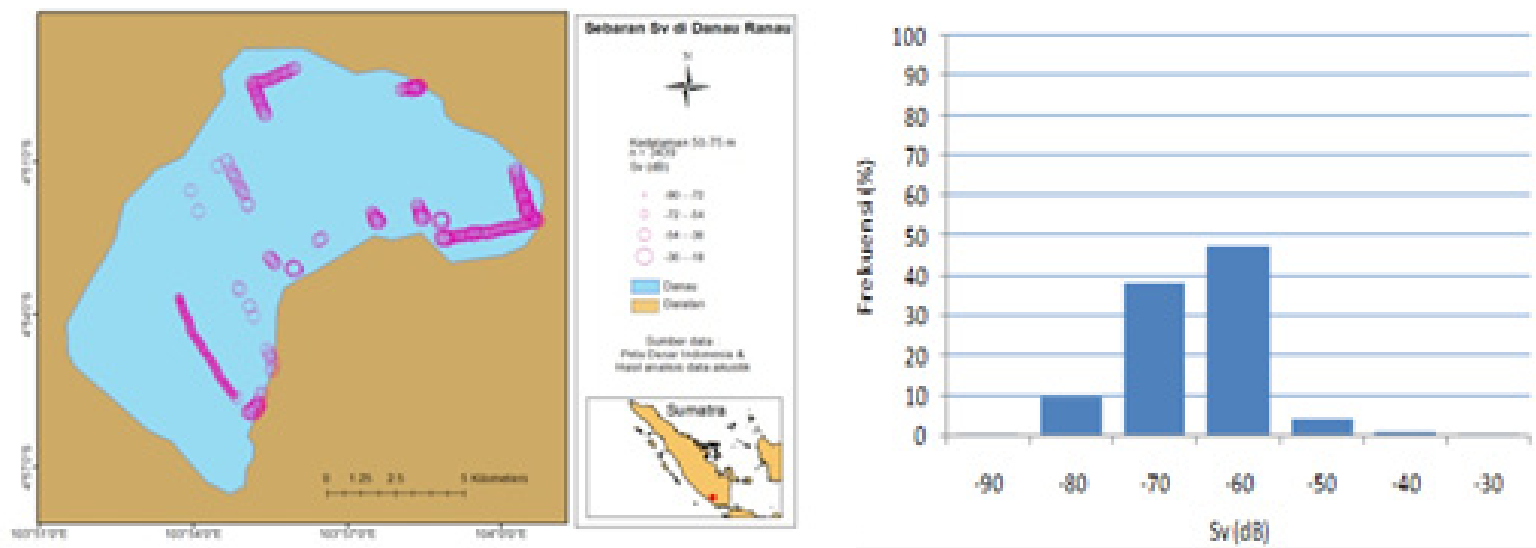

(c)

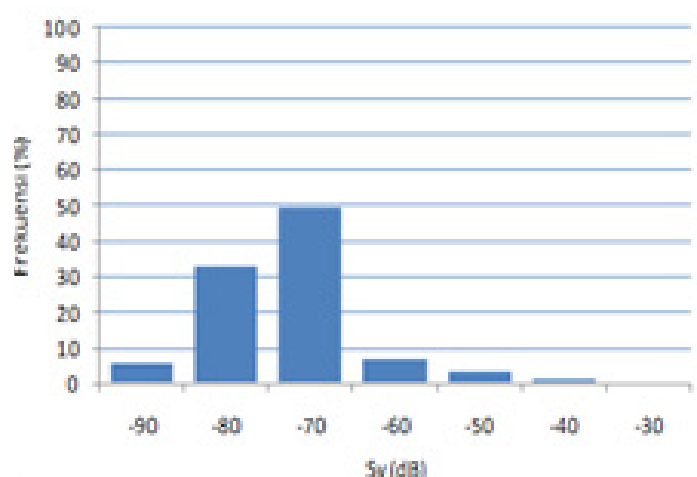

Gambar 3. Sebaran Sv (dB) tiap kedalaman (kiri) dan sebaran ukurannya (kanan) (b: 25$50 \mathrm{~m}$; c: $50-75 \mathrm{~m})$
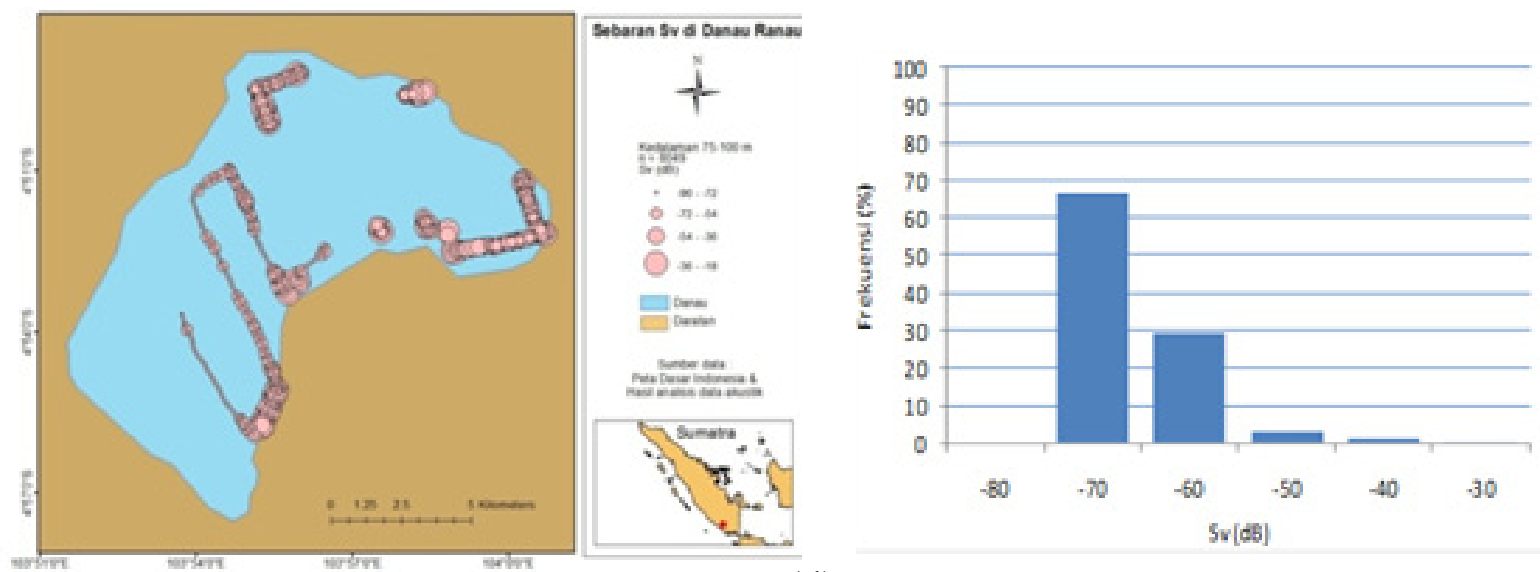

(d) 

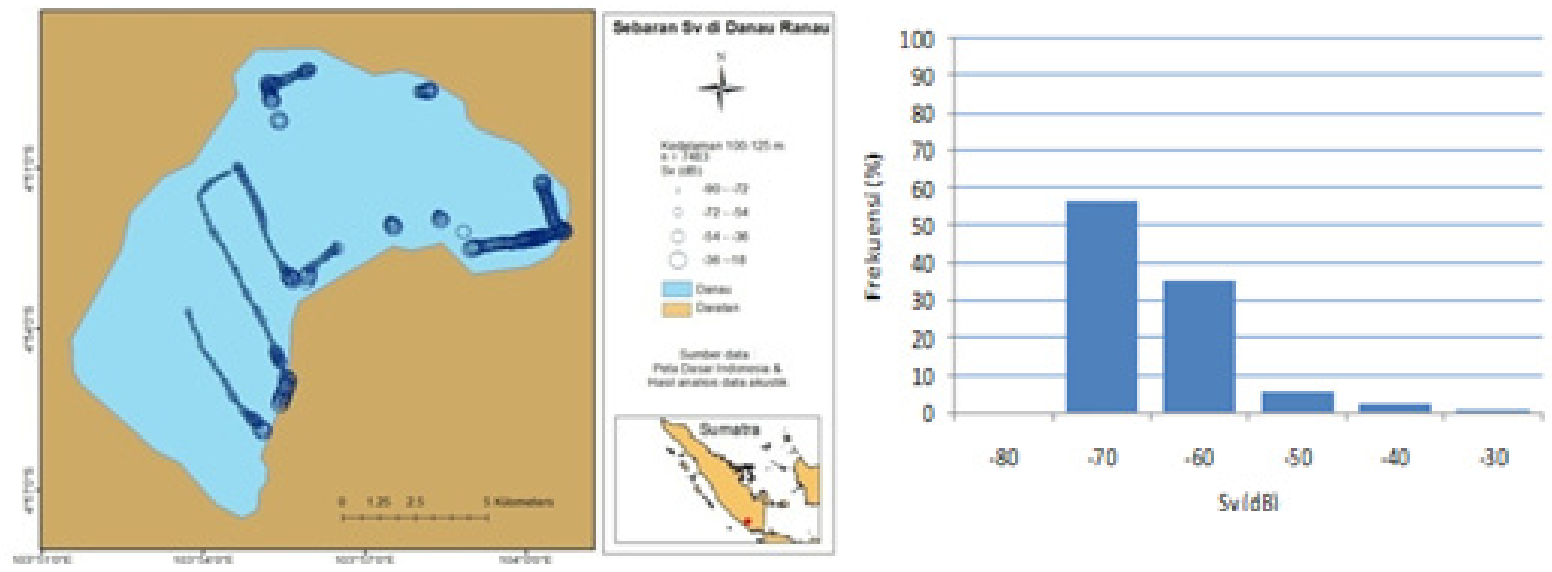

(e)

Gambar 4. Sebaran Sv (dB) tiap kedalaman (kiri) dan sebaran ukurannya (kanan) (d: 75$100 \mathrm{~m}$; e: $100-125 \mathrm{~m}$ )

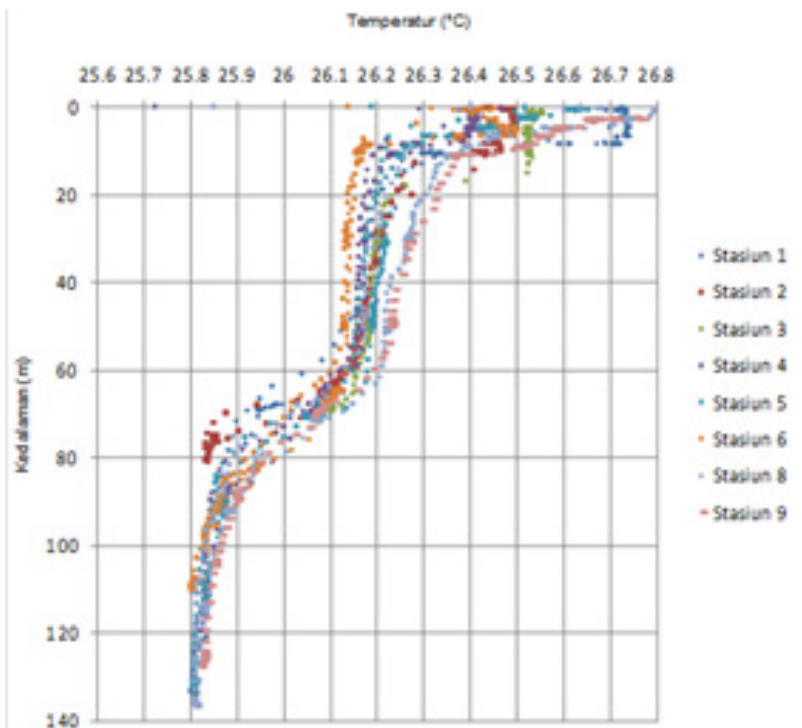

(a)

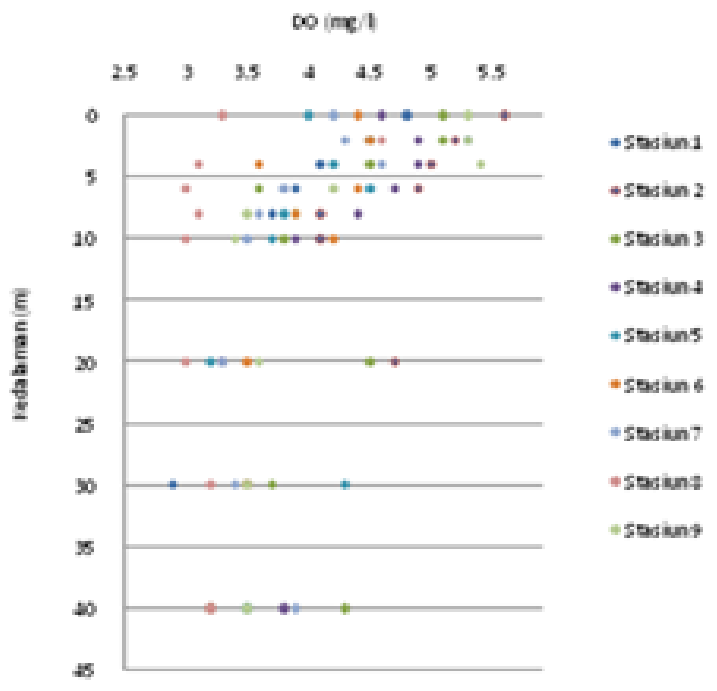

(b)

Gambar 5. (a) Profil menegak suhu dan, (b) DO pada Bulan Februari 2013 di Danau Ranau, Sumatera Selatan

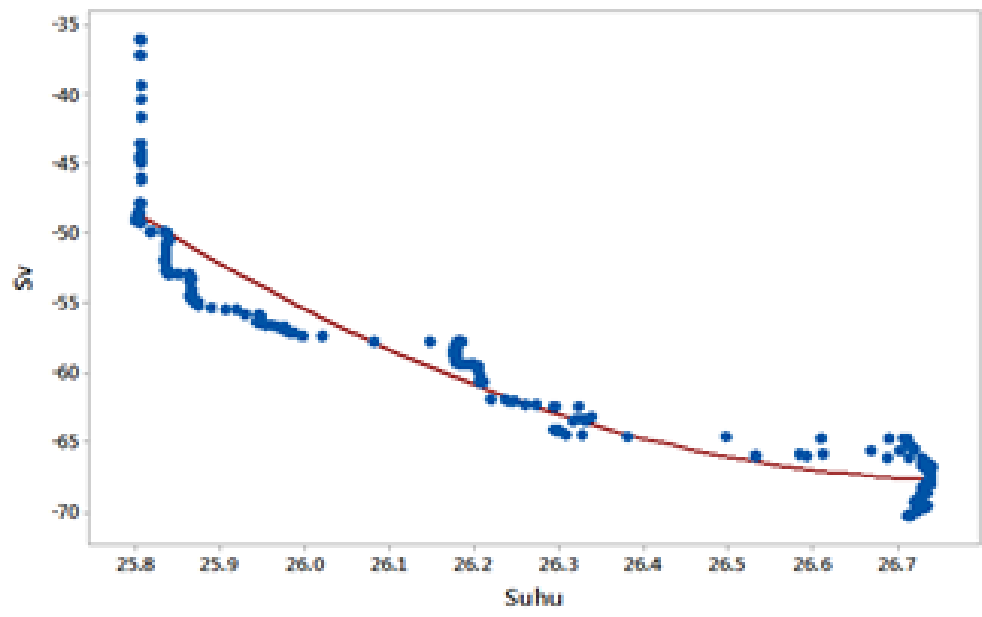

Gambar 6. Hubungan antara variabel Sv dan suhu 


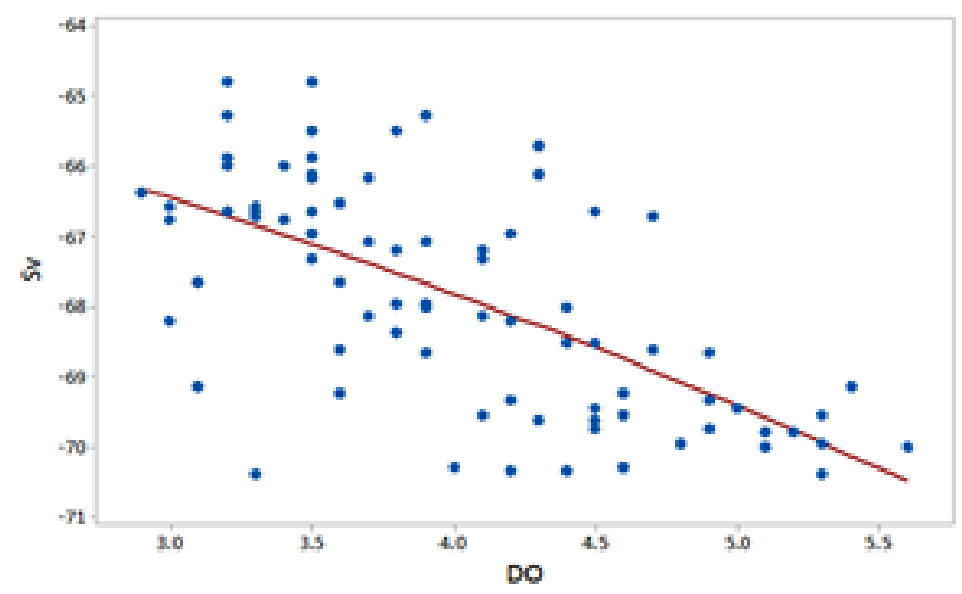

Gambar 7. Hubungan antara variabel Sv dan DO

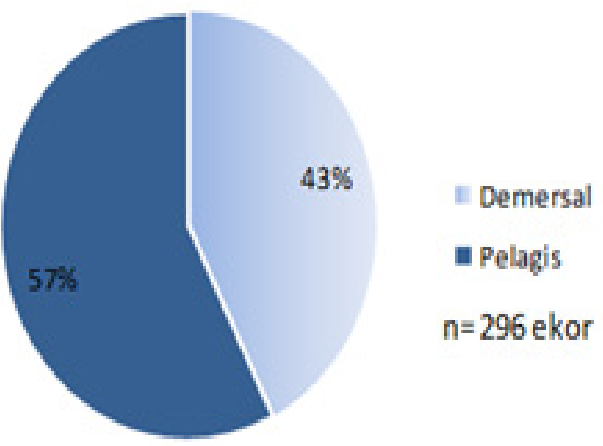

Gambar 8. Proporsi ikan pelagis dan demersal di Danau Ranau

\section{Hubungan antara Sv dan suhu serta Sv dan oksigen terlarut (DO)}

Hubungan antara Sv dan suhu dinyatakan dalam persamaan regresi kuadratik, karena ada kecendrungan kebutuhan suhu maupun oksigen oleh makhluk hidup dalam hal ini ikan tidak terus menerus tinggi, melainkan ada suhu tertentu atau batas optimum untuk kepentingan tertentu. Suhu air yang optimal untuk pertumbuhan ikan pada umumnya berkisar antara $28^{\circ} \mathrm{C}-32^{\circ} \mathrm{C}$. Dalam penelitian ini, antara Sv dan suhu memiliki keeratan yang sangat kuat ( $\mathrm{r}=0.94)$ (Gambar 6). Sementara Sv dan DO tidak memiliki keeratan yang cukup ( $\mathrm{r}=0.65)$ (Gambar 7$)$.

\section{Perikanan di Danau Ranau}

Hasil tangkapan nelayan didominasi oleh ikan pelagis (Gambar 8). Ikan pelagis yang terdapat di Danau Ranau berasal dari famili Pristolepididae, Notopteridae, Cyprinidae, serta Cichlidae. Pristolepididae dan Cyprinidae merupakan famili yang dominan. Cyprinidae sebagaimana diketahui merupakan famili dengan jumlah spesies terbesar di dunia ( $>2010$ spesies) dan tersebar secara luas (Berra 2001). Umumnya nelayan di Danau Ranau melakukan penangkapan ikan menggunakan jaring insang, sebagian kecil menggunakan bubu, panah, pancing dan jala. Jaring yang digunakan berbahan nilon no. 12-15, berukuran panjang $1-5$ pis $(1$ pis $=100 \mathrm{~cm})$, lebar $3 \mathrm{~m}$ dengan lebar mata jaring 2.50 hingga 4 inci, jarak antar pelampung 0.50 hingga $1.50 \mathrm{~m}$. Terdapat 7 unit keramba jaring apung (KJA) yang terletak di Way Wangi pada tahun 2013, khusus untuk budidaya ikan nila (Oreochromis niloticus). Sementara 500 kepala keluarga (KK) mengelola keramba tancap/hampang (pen culture) yang tersebar di Kota Batu, Tanjung Wangi dan Way Wangi, untuk budidaya ikan mas, patin, bawal, gurame, lele dan mujair.

Perikanan yang berkembang di Danau Ranau meliputi perikanan tangkap dan perikanan budidaya. Data statistik menunjukan bahwa potensi produksi ikan di perairan umum baik di wilayah OKU Selatan maupun Lampung Barat didominasi oleh perikanan budidaya. Sebagaimana kondisi 
perikanan di beberapa perairan umum, perikanan budidaya cenderung mengalami peningkatan dari tahun ke tahun. Pemerintah setempat umumnya fokus pada budidaya KJA, sehingga perkembangan perikanan budidaya sangat jauh lebih tinggi dibandingkan dengan perikanan tangkap, padahal jauh sebelumnya telah direkomendasikan perlunya keseimbangan antara budidaya ikan dan intensifikasi penangkapan di Danau Ranau guna menjadikan sektor perikanan sebagai yang utama (leading sector) bagi penyokong kehidupan masyarakat di sekitarnya (Kartamihardja \& Utomo 2000).

\section{Karakteristik ikan pelagis dan habitatnya}

Ikan pelagis adalah organisme yang mampu berenang melawan arus di perairan terbuka. Pada umumnya ikan ini hidup di zona kolom perairan dan bersifat bergerombol. Sebaran ikan pelagis dipengaruhi oleh lingkungan, ikan ini suka hidup di daerah yang masih mendapat sinar matahari (daerah eufotik) dengan kisaran suhu antara $28-30{ }^{\circ} \mathrm{C}$. Jika intensitas cahaya tinggi (siang hari), ikan turun sampai kedalaman 12-22 m. Namun pada malam hari ikan menyebar merata di kolom air (Laevastu \& Hayes 1981)

Habitat pelagis meliputi frontal zone (merupakan batas antara massa air yang memiliki perbedaan suhu dan salinitas), oksigen, nutrien, salinitas (di laut) dan gradien suhu (Sharp 1987, Cushing, 1995 dalam Jones et al. 1999). Seperti kelimpahan Cyprinidae yang bervariasi terhadap kecepatan arus sementara keragamannya dipengaruhi oleh dinamika oksigen dan alkalinitas (Beamish et al. 2006). Ikan-ikan yang banyak tertangkap di Danau Ranau merupakan jenis ikan yang hidup di habitat litoral atau tepi danau, misalnya putak (Notopterus notopterus) dan palau (Osteochilus hasselti). Pada umumnya ikan-ikan tersebut merupakan ikan sungai yang cenderung bermigrasi, demikian hal nya jenis harongan (Hampala macrolepidota) dan kepor (Pristolepis fasciatus), yang merupakan ikan sungai, bermigrasi dan menyukai perairan berarus (IUCN 2012).

\section{KESIMPULAN DAN SARAN}

\section{Kesimpulan}

Sebaran Sv secara spasial di Danau Ranau tidak merata. Secara vertikal, ukuran kelompok ikan terbesar ditemukan di kedalaman 100-125 m (-76.4 sampai -31.5 dB) dan terkecil terkonsentrasi pada kedalaman 0 hingga 75 m (-90.9 sampai -34.9 dB), yang berarti ukuran Sv semakin besar seiring dengan bertambahnya kedalaman. Kepadatan Sv ditemukan maksimum pada kedalaman 75-100 $\mathrm{m}$ dan terendah pada 0-25 m. Secara horisontal, Sv berukuran kecil (kisaran -90 sampai -70 dB) banyak dijumpai di sisi barat danau sementara ukuran besar dijumpai di sisi timur dan tenggara danau $(-50 \mathrm{sd}-30 \mathrm{~dB})$. Sv memiliki dan suhu memiliki keeratan yang sangat kuat $(\mathrm{r}=0.94)$ sementara $\mathrm{Sv}$ dan DO tidak memiliki keeratan yang cukup ( $\mathrm{r}=0.65)$.

\section{Saran}

Pada penelitian selanjutnya disarankan untuk melakukan survei akustik pada siang dan malam hari, sehingga gambaran sebaran ikan dapat dijelaskan sesuai dengan karakteristik jenis ikan tertentu yang melakukan migrasi harian secara vertikal dan horisontal. Penggunaan alat tangkap tidak selektif disarankan untuk meningkatkan keakurasian dalam menginterpretasi hasil.

\section{DAFTAR PUSTAKA}

Beamish FWH, Sa-ardrit P, Tongnunui S. 2006. Habitat Characteristics of the Cyprinidae in Small Rivers in Central Thailand. Environmental Biology of Fishes. Vol. 76 issue 2-4 : 237-253

Berra TM. 2001. Freshwater fish distribution. Handbook. Academic Press.

Echoview. 2009. Echoview modules. Echoview helpfile for echoview.

Fishbase. 2012.www.fishbase.org. hampala macrolepidota. (diacu 2012 Desember 27). Tersedia dari: http://www. fishbase.org/summary/4803

Higginbottom I., and Pauly T. (1997) Echo integration in low signal to noise regimes: methods of noise estimation and removal. CCAMLR Working Group on Ecosystem Monitoring and Management paper WG-EMM-97/74.

[IUCN] International Union for Conservation of Nature. (diacu 2012 Desember 27) tersedia dari: http://www.iucnredlist. org/details/181255/0

Johannesson KA dan Mitson RB. 1983. Fisheries Acoustic a Practical Manual for Aquatic Biomass Estimation. FAO. Fisheries Technical Paper. Roma. 
Jones KMM, Fitzgerald DG, Sale PF. 1999. Comparative Ecology of Marine Fish Communities. Handbook of Fish Biologi and Fisheries. Volume I Fish Biology. Blackwell Publishing.

Jurevičs P, Škute A, Brakovska A, Stepanova M. 2012. Spatio Temporal Distribution of Fish in the Northern Part of Lake Svente. Acta Biol. Univ. Daugavp., Suppl. 3, 2012: 50 - 61.

Kartamihardja ES dan Utomo AD. 2000. Biolimnologi dan rencana pengelolaan perikanan di Danau Ranau, Sumatera Selatan. Prosiding semiloka nasional pengelolaan dan pemanfaatan danau dan waduk, Bandung 7 November 2000. Jurusan Perikanan Fakultas Pertanian Universitas Padjadjaran. P14.

Laevastu T, Hayes ML. 1981. Fisheries Oceanography and Ecology. [In:] Georgakarakos, S., Dimitra, K. 2008 Mapping abundance distribution of small pelagic species applying hydroacoustics and co-kriging techniques. Hydrobiologia 612.

Mason DM, Johnson TB, Harvey CJ dkk. 2005. Hydroacoustic estimates of abundance and spatial distribution of pelagic prey fishes in western lake superior. Journal of Great Lakes Res. 31:426-438.

Peters JA, Lodge DM. 2009. Littoral Zone. Chapter Lake ecosystems: structure, function and change. Lake Ecosysytem Ecology. Encyclopedia of inland waters: a global perspective.

Samuel S, Aida N, Makmur S, Subagja. 2010. Perikanan dan Kualitas Lingkungan Perairan Danau Ranau dalam Upaya
Pelestarian dan Mendukung Produksi Hasil Tangkapan Nelayan. Laporan Akhir Riset. BRPPU - BRKP.

Simmonds EJ dan MacLennan DN. 2005. Fisheries Acoustic : Theory and Practice 2nd ed. Blackwell Science Ltd.

Strayer DL. Benthic invertebrate fauna, lakes and reservoirs. Chapter Lake ecosystems: structure, function and change. Lake Ecosysytem Ecology. Encyclopedia of inland waters: a global perspective.

Sulastri, M. Badjoeri, Y. Sudarso dan M.S. Syawal. 1999. Kondisi fisika-kimia dan biologi perairan Danau Ranau Sumatera Selatan. Pusat Penelitian dan Pengembangan Limnologi, Lembaga IImu Pengetahuan Indonesia. LIMNOTEK. Vol. VI(1):25-38.

Sumanto MA. 2014. Statistika deskriptif (untuk mahasiswa, dosen dan umum). Caps Publishing.

Welcomme, R.L. 2001. Inland Fisheries Ecology and Management. Fishing News Books. Oxford

Widodo J. 2002. Pengantar Pengkajian Stok Ikan. Pusat Riset Perikanan Tangkap. Badan Riset Kelautan dan Perikanan. Departemen Kelautan dan Perikanan. Jakarta.

Yamin S, Rachmach LA, Kurniawan $H$. 2011. Regresi dan korelasi dalam genggaman anda, aplikasi dengan software SPSS, EViews, MINITAB, dan STATGRAPHICS. 